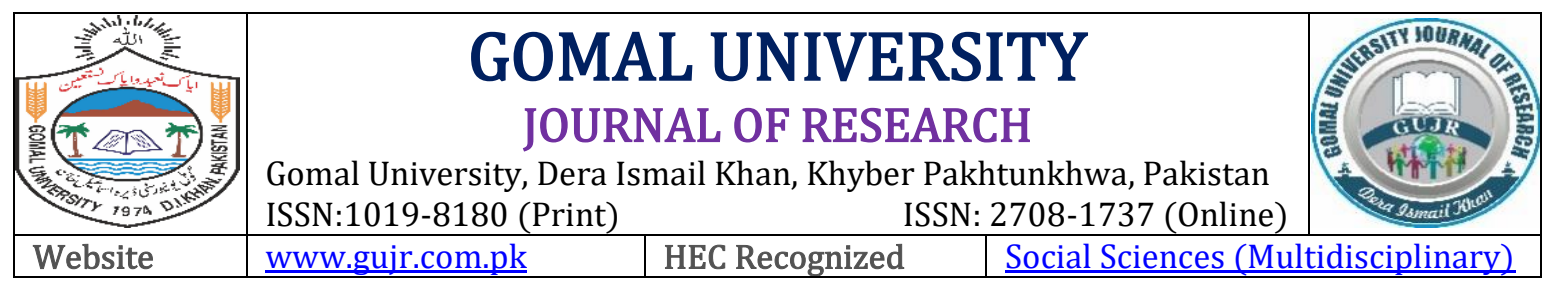

\title{
IMPACT OF ETHICS, STRESS AND TRUST ON CHANGE MANAGEMENT IN PUBLIC SECTOR ORGANIZATION
}

\author{
Sayed Fayaz Ahmad ${ }^{1}$, Muhammad Ibrahim² \& Abid Hussain Nadeem ${ }^{3}$ \\ ${ }^{1}$ Assistant Professor, Institute of Business Management (IBM), Karachi, Pakistan \\ ${ }^{2}$ Assistant Professor, Department of Management Sciences, KFUEIT, Rahim Yar Khan \\ ${ }^{3}$ Assistant Professor, Department of Management Sciences, KFUEIT, Rahim Yar Khan
}

\begin{tabular}{|c|c|}
\hline ARTICLE INFO & ABSTRACT \\
\hline $\begin{array}{l}\text { Keywords: } \\
\text { Facilitation (F), Ethics } \\
\text { (E), Trust (T), Stress } \\
\text { (S) \& Change } \\
\text { Management (CM) }\end{array}$ & $\begin{array}{l}\text { The aim of the study is to find out a successful way of managing the } \\
\text { organizational change in public sector organizations. The research is } \\
\text { based on a structured questionnaire survey. The data was collected in } \\
\text { some of the top public sector organizations in Pakistan. The study } \\
\text { suggests that Stress, Trust, and Ethics have a strong relationship with } \\
\text { Organizational Change Management. Organizations must minimize } \\
\text { the workplace stress, maximize trust of workers on management and }\end{array}$ \\
\hline $\begin{array}{l}\text { Article History: } \\
\text { Date of Submission: } \\
\text { 15-09-2020 } \\
\text { Date of Acceptance: } \\
\text { 18-03-2021 } \\
\text { Date of Publication: } \\
\text { 31-03-2021 }\end{array}$ & $\begin{array}{l}\text { organization and ensure ethics for organization change management. } \\
\text { The managerial implication of the research is, bringing and making } \\
\text { any organizational change is very difficult without employee-friendly } \\
\text { working environment of the organization. The results of the study } \\
\text { make it easy, how to put employees on the right track for achieving } \\
\text { organizational goals and objectives in any Organizational Change by } \\
\text { using Facilitation. }\end{array}$ \\
\hline Corresponding Author & Muhammad Ibrahim: muhammad.ibrahim@kfueit.edu.pk \\
\hline DOI & https://doi.org/10.51380/gujr-37-01-05 \\
\hline
\end{tabular}

\section{INTRODUCTION}

To address how the organization implements the change strategy effectively, there is need to find out a way how to do it. This research is conducted to bridge gap between change and employee resistance. There is saying, Organization does not change, its people change and then they change it. The adage is absolutely correct and before changing an organization to the desired position, the management needs to change the employees. The process used to put the organization's workers on required path for the desired goals and to guide them on how to achieve these goals is called Facilitation. This is a technological era. Firms around the world are expending a lot of money and efforts for capturing maximum market share, design their strategies according to market demand and to survive in present competitive market (Dickey \& Colin, 2015). Modern technology has also pushed organizations into a very competitive environment. For this purpose, organizations use an approach to get their desired position by shifting their workers or organization from their original position to desired one. This process is known as Change Management (Hayes, 2014). There are 
many ways, methods and tools which "change management" uses in their organizational change management effort. Change is a continuous process in all organization, and it will be true and of importance to mention here that organizations only spend money and other resources to improve its speed for reaching the destination successfully through desired standards (Marquis \& András, 2013).

Achieving change is not as easy as people write and talk about. It requires visionary management and expensive organization's efforts. It is the duty of higher management to put the workplace's environment in an acceptable position to stay in the contemporary advanced technological in the competitive market (Skelsey, 2013). As the technology changes with each passing day wherein companies spend a huge amount on Resource and Development, is alarming for those which are less technological and whose management is less motivated and acquainted with the importance of organizational change (Kotter's 8-Step Change Model Mind Tools, 2016). The CM remained the need of all time and due to its importance, many renowned researchers came forward and worked on it. Some of the main theories regarding it are: the Lewin's Model (Lewin, 1947), McKinsey $7 \mathrm{~S}$ theory (Hayes, 2014), Kotter's change management theory (Editorial Team, 2016), Nudge Theory (Simon \& Marco, 2018), ADKAR model (Creasey, 2019), Bridges' Transition Model (William, 2004), Kübler-Ross Five Stage Model (Broom, 2004). These are the leading theories presented by researchers and thus this study is based on the above theories and the concepts discussed there. Its summaries and focuses on organizational factors necessary for any change in an organization under the themes of trust, ethics, and stress. These factors are discussed in the literature review thoroughly.

Now the question is how to get these changes. This research has following objectives to reach the conclusion:

1. To find out the impact of stress on the organizational change management.

2. To find out the impact of trust over the organizational change management

3. To find out the impact of ethics on the organizational change management

4. To find out the role of facilitation in minimizing stress, maximizing trust, and ensuring ethical environment.

\section{LITERATURE REVIEW}

The management of the organization facilitates its employees in their working environment for attaining these goals. They also try to promote the group work and make a friendly organizational environment (Upadhaya, Munir \& Blount, 2014). The term facilitation seems to have come into the existence from helping in making a successful meeting and student-centered learning (Rogers, 1994). The process of facilitation helps peoples to realize the activities which they have to perform and know the change aspects of their attitudes, work activities or to change their behavior about their surroundings (Marshall \& McLean, 1988) in order to attain desired standards through their efforts.

\section{Facilitation}

Facilitation plays an important role in any organization change process. Some of strategies which contribute to the management of organizational change are training and social influences that are crystal clear from the evidence (Oxman, 1994). But it should be kept in mind that there are some methods that are more effective than others in many environments and with the help of certain approaches the desired organizational change can be achieved and the desired strategies that can implemented effectively. These approaches combine set of different roles and different techniques (Bero, Grilli, Grimshaw, Harvey, Oxman \& Thomson, 1998). Facilitation also includes different types of the technological and practical support in the change management process (McCormack 
\& Garbett, 2001). The facilitators provide compulsory knowledge about modern technology which is necessary for achieving the organizational changes. This includes the introduction of modern technology usage and obligatory use of the existing technology (Rush, 2015). Many studies also consider facilitation as the mean of addressing the problems and issues like team building and its performance (Hills \& Harvey, 2000). In other words, in this process, the difficulties are decreased in the workplaces with the help of facilitators by establishing such an environment which is more conducive and facilitative that is in favor of both organization and concerned employees (Hogan, 2013).

In this paper, facilitation is used for the practice, which enables employees to accept organizational change and effectively implement the management desired strategy in the organization. In this research, the importance of facilitation was addressed for making the organization environment suitable for acceptance of the required organizational change. It is also proposed by research that the most important role can be played by a facilitator in getting the individuals and groups on the right track of achieving the desired changes (Metz, 2013). Facilitators can use their strong and effective interpersonal skills in achieving these goals (Kitson, Harvey \& McCormack, 1998). From the above literature survey, provide significant information about these concepts as it is extracted that the process of facilitation is objectively focused on the experimental learning having a strong relationship amid individual psychological aspects, attributes and challenging cultural and societal norms.

\section{Ethics}

Ethics is derived from "Ethos", which is the Greek word and means character. The concepts and ideas that define and systematize code of conduct for human. Human moral behavior and preferred way of their acts are the focal points of study of ethics (http://www.iep.utm.edu/ethics/). Ethics is different from religious beliefs, traditions and law; and is defined as, "the set of concepts and principles that guides in determining what behavior helps or harm sentient creatures" (Paul \&, Linda, 2006). There are four main types of the ethics, Meta-Ethics, Normative Ethics, Applied Ethics, and Descriptive Ethics. There are two types of judgment in this word. One is right and the other is wrong. Then it is important to be known how people think and decide what is right and what is wrong. How they know about it and how they mean? (Armstrong, 2019). When the people are talking about something as wrong or right, they are expressing their emotions not something else. And based on their emotional feeling they decide what is false and what is true (http://www.iep.utm.edu/non-cogn/). When people are doing something then how they need to categorize that they are doing right or wrong (Cabrera, 2018). The best example of this scenario is, if someone says that smoking is always wrong then it should find out that how he/she thinks like that. All the actions and thinking about these actions are studied in the vital ethics (Preface, 80130).

Organizations consist of people who come from different sects, colors and races. Therefore, moral and ethical problems arise (Ahmed, 2011). These issues include all regarding business, individuals or organization conducts (Scott \& Richard, 2008). It is of great importance for employers to know the best business behavior and the ethical issues that have a great impact on the elements which maximize profit and make the business environment more satisfactory for employees (Ibrahim, 2015). For this purpose, not only, organization implements a policy regarding ethical behavior but the government also uses specific regulations and laws (Oliveira \& Fabrice, 2019). Ethics are more important than government regulations because they are beyond the control of the government (Berle \& Means, 1932). Based on the above literature, it is extracted that the ethical development of minds is very necessary for assuring the employees about organizational change management. They will know what the organizations do is for the benefits of workers and the organization itself. 
An organization can provide such an environment only if there are ethical and moral values. Thus, it is of immense importance for employers to facilitate concerned organization regarding ethics for effective organizational change management. The following hypothesis are thus supposed to be true.

H1: Facilitation has a positive impact on Ethics.

H2: Ethics has a positive relationship with Organizational Change Management.

\section{Stress}

In this study, stress is considered a workforce place stress. Feelings of an employee that he/she is not treated well by the organization/ supervisors (Cohen, Murphy \& Prather, 2019; WHO, 2015). It affects a person physically and psychologically. It occurs when the worker is not able to perform as organization require from them (Henry \& Evans, 2008). There are many reasons for occupation stress but important among them are high workload, lack of the independence, dissatisfying work environment, negative role of management, and less advancement of job levels (Mark \& Smith, 2008) Stress leads organization performance to a poor and low level, it may increase absenteeism and decrease productivity. It is also related to many biological disorders and may cause even death (Burns, Peter \& Kaarin, 2016). There are two types of stress, eustress, and distress. In this paper, we have considered stress for distress only, which is a reaction to the negative events. It is very big problem in today organization's environment, and sometimes very costly and dangerous (Kingston \& Stekhoven, 2016). There is strong evidence that workplace stress is more in females than in males (OfficePro, 2010). Stress comes from situation when an individual fails to perform as organization demands from him/her (Shahab, 2018). Different individual traits have different impacts on job stress and individuals with diverse traits are affected by stress differently (NIOSH, 1999).

One other reason for stress is the less and insufficient coping ability of an individual. Therefore, when the situation is too far to handle for an individual and is alarming for his/her well beings, he/she will come under stress (Dopkeen \& Renee, 2014). In today's work environment, employees are in high-level stress due to the less knowledge and skills. Most of workers are old and unaware of usage of modern technology (Liu, Spector \& Shi, 2007). As a result, they fail to perform enough well as the organization demands from them. In reaction to high stress, the employees start using alcohol and may suffer from other behavioral problems like feeling powerless and less moral (Dopkeen \& Renee, 2014). It also decreases innovation and decision-making power and increases absenteeism, workplace accidents, and turnover (Teasdale, 2006). The above literature makes it clear that proper management of stress is very important and so combined effort of both workers and organization is necessary for it. Usually, stress is managed through a combination of stress management and organizational change. In this connection, the researcher has supposed that the facilitation may help in decreasing workforce apprehension/ stress and thus assumed following hypothesis.

H3: Facilitation has a negative impact on workplace stress.

H4: Workplace Stress has a negative relationship with change management.

\section{Trust}

Trust is one of the main factors which not only affect the behavior of a worker but also the image and future of an organization (Dinesen, Merlin \& Kim, 2020). The definition of trust is difficult to be written in a single sentence and referred to a state of affair when one party will rely upon the deeds of the second party, which have control over all of circumstances and where the situation is future-directed (Bamberger \& Walter, 2010). Trust is very important for the society because it operates at the edge of experience and new possibilities. For the smooth running of society, trust 
is also necessary for the reduction of many complexities and provides a platform for allowing the desired actions (Bachmann, 2001). Trust reduces the cost of the transaction and other dealings between parties and enabling them to do business free from fear and terror (Awan, 2011). It also enhances the different activities of business, employment and brings prosperity (Zheng, Roehrich \& Lewis, 2008). This importance made trust as valuable as other capital for the organizations and compelled them to think about how this capital will be generated, increased, and distributed. It is also widely accepted that trust and the economic development is positively correlated (Fukuyama, 1996).

The intensity of trust differs from individual to individual and strongly based on personal features and it is argued that it maximizes subjective well-being as it increases interpersonal relationships (DeNeve, 1999). Sometimes such situations come when it is impossible for the party to select one side and it is very difficult to satisfy the other side. In such situations, Trust is the only means and is used as alternative to control where control over described situation is quite difficult to obtain (Mollering, 2005). Today we are living in the modern society and information technologies have made the path clear for transition towards postmodern society (Nooteboom, 2017). Trust plays a significant role in the modern technological era. The employees have to trust their organizational technological change is beneficial for them and in response, organizations have to trust engineers and technology operators (Lacohée, Cofta, Phippen \& Furnell, 2008). The discussion regarding Trust and technology relationship is in its growth period and is unified into a socio-technical view from the social actor's perspective on trust (Cofta, 2007). This research has also selected trust as one of variables which are strongly correlated with the characteristics and behavior of a person. The research looks for the facilitation's influence over the trust and trust's influence over change management. In this connection, based upon the existing literature, study assumed the following hypothesis:

H5: Facilitation has a positive correlation with Organizational Trust of employees

H6: Trust and Change management in organizations are positively correlated.

\section{Change Management in Public Sector Organizations}

Every country has two main types of organizations, Public and Private sector organizations. In the first type of organization, civil officials and public boards have power and authority of managing the organization on the behalf of public. There is no way for the common public to express their satisfaction or dissatisfaction with state of affairs of these organizations. Therefore, there seems to be wide managerial discretionary attitude and behavior in public sector organization management (Scott \& Richard, 2008). The organization consists of employees, having a position from clerk to the CEO. Usually, the higher management tries to save money as their first priority. They directly impose their policy over the middle and lower management to do so. Therefore, it is of immense importance to study how the higher management achieves the goals and objectives which are in the best interest of their country, organization, and the organizational employees (Creasey, 2019). We must accept that the management of these organizations is free to a large extent to pursue the goals of their own choice. And it is necessary to be questioned that what are their goals and what is the effect of these goals on overall output of organization (Wherrett, 2020). In this connection, the management will reject the goals which are not interesting for them and will work for those which thus motivate them. This phenomenon has been studied by many researchers (Williamson, 1964).

Management in large public sector organizations has enough power to implement policies, which seem to be most satisfactory for them. Their power can be recognized from their position and the subordinate's job characteristics and numbers under their control (Public sector, 2016) There is another study, which presents that the management of public sector organization would surely 
consider organization long-term objectives and interests and would surely reconcile the personal motivations and goals with the organizational objectives and goals (Marris, 1964). Another study proposed that managers work in teams at these organization. Every person has his/her own goals and objectives. Therefore, they have to take into account objectives of other organizations (The Center for Responsive Politics, 2017). Hence a very complex bargaining process begins between various members, within a group or outside group in the determination of their collective goals and objectives (Cyert \& March, 1963). The most important matter of interest is the spending of public money in these organizations. The management knows that nepotism and corruption may be investigated and rewarded negatively (Barlow, Roehrich \& Wright, 2010). So, management tries to expand these organizations and develop new and public welfare services to the public. One other reason for keeping public sector organization in healthy condition is political (What is the Public Sector? Definition \& Examples, 2016). There is an opposite force which is constantly imposing itself on the management of public sector organization. This force is called resistance to change. It is clear from previous researches that the employees who have worked under old work environment will oppose the innovation, new method, and environment of working (Machiavelli, 1993).

There are many reasons which compel them to oppose the changes. Among them some important are, lack of information and less knowledge about the change, status, and failure fear. They even don't know the actual benefit of the change for which the change is going to be done (Thomson, 1993). One another reason for resistance is the control of the management from outside or higher level. The employees feel threatened by their power and position and feel fear that their position will be disturbed (Anderson, 2013). Some of the main theories regarding it are: Lewin's Model (Lewin, 1947), McKinsey $7 \mathrm{~S}$ theory (Hayes, 2014), Kotter's change management theory (Editorial Team, 2016), Nudge Theory (Simon \& Marco, 2018), ADKAR model (Creasey, 2019), Bridges' Transition Model (William, 2004), Kübler-Ross Five Stage Model (Broom, 2004). This study is based on above theories having a focus on human factors on business transition. As an important part of the change and agent for change, they have most powerful impact on change management. The study assumes that three main factors stress, trust, and ethics are most important factors for any change in organization. Without ethical environment, employees trust and less stress, brining change will be very difficult. This finds out need for facilitation of improving Ethics, minimizing Stress and ensuring trust and impact on organizational change management as given in theoretical model.

\section{Figure 1}

Theoretical Model

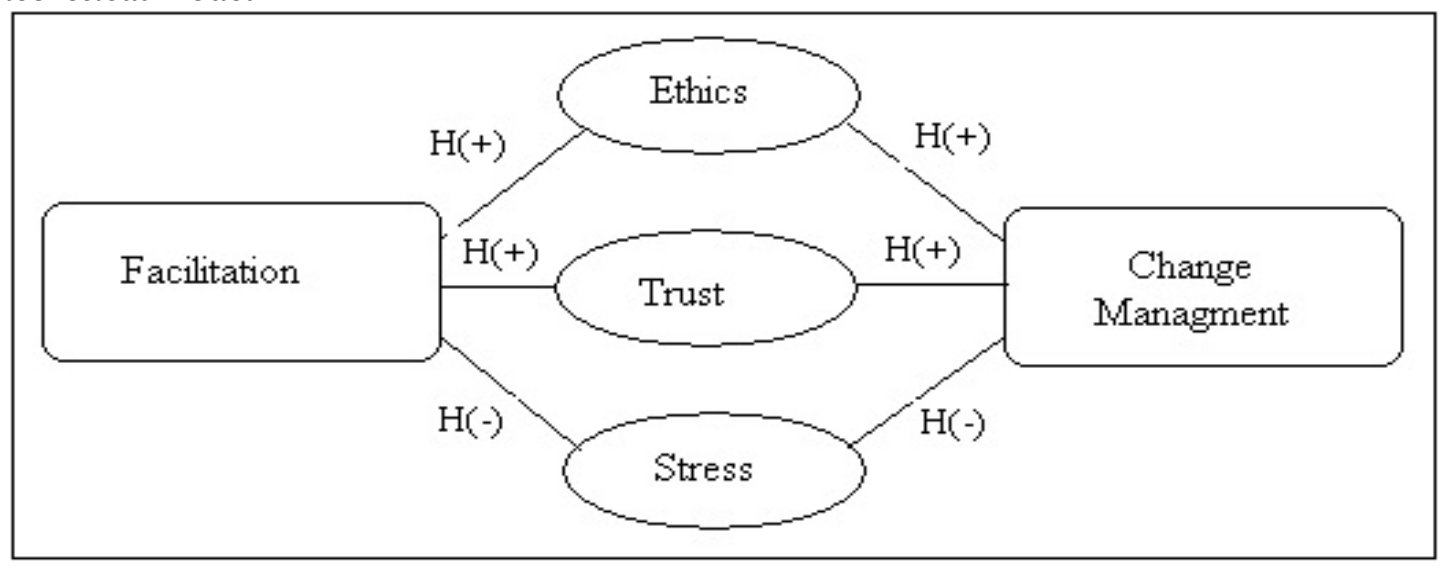




\section{RESEARCH METHODOLOGY}

The study is based on quantitative research method. After thorough literature review hypotheses were derived. For each assumed the relationship, questionnaires were developed, distributed and collected back from the respondents. Employees from the public sector organizations were chosen survey. In this connection, the numbers of the respondents selected were 255, and the sampling method was random sampling method. After getting back the questionnaire, 250 responses were found fit for consideration in the research. Thus, the data were analyzed through SPSS software and the correlation analysis was used for finding the relationship between the variables of our interests.

\section{RESULTS AND ANALYSIS}

After conducting a questionnaire survey, the data was inserted in SPSS for analyzing and results. In order to chase the desired objectives systematically, first of all, the reliability of the data was checked and after finding out reliability statistics, correlation between various variables was find out.

\section{Reliability Test}

Before carrying out the research survey, the questionnaires were tested and found to be fit for the research with the Chronbach Alpha value of 0.87. Consequently, after that review, the complete questionnaire survey was made and data collected were analyzed through SPSS tools for finding objectives.

\section{Correlation Analysis}

H1: Facilitation has positive impact on Ethics: Results show that there is a positive and significant relationship amid Facilitation and Ethics. The correlation provides significant information about association. This authorizes our assumption that the Facilitation has positive impact on Ethics". Following table shows details of results which is correlation value $0.441\left(^{* *}\right)$ and significance level 0.000.

H2: Ethics has a positive relationship with Change Management: Results also show that there is a positive and significant relationship between ethics and organizational change management. This authorizes our assumption that "Ethics has a positive relationship with change management". The following table shows details of results which is correlation value $\left.0.500{ }^{* *}\right)$ and significance level 0.000.

\section{Table 1}

Correlation Analysis

\begin{tabular}{|c|c|c|c|c|c|c|c|}
\hline & & $F$ & $E$ & $S$ & $\mathrm{~T}$ & $\mathrm{CM}$ & Alpa \\
\hline $\mathrm{F}$ & $\begin{array}{l}\text { Pearson Correlation } \\
\text { Sig. (2-tailed) }\end{array}$ & 1 & & & & & .789 \\
\hline $\mathrm{E}$ & $\begin{array}{l}\text { Pearson Correlation } \\
\text { Sig. (2-tailed) }\end{array}$ & $\begin{array}{l}.441\left(^{* *}\right) \\
.000\end{array}$ & 1 & & & & .771 \\
\hline S & $\begin{array}{l}\text { Pearson Correlation } \\
\text { Sig. (2-tailed) }\end{array}$ & $\begin{array}{l}-.402(* *) \\
.000\end{array}$ & $\begin{array}{l}.446(* *) \\
.000\end{array}$ & 1 & & & .763 \\
\hline $\mathrm{T}$ & $\begin{array}{l}\text { Pearson Correlation } \\
\text { Sig. (2-tailed) }\end{array}$ & $\begin{array}{l}.543(* *) \\
.000\end{array}$ & $\begin{array}{l}.369(* *) \\
.000\end{array}$ & $\begin{array}{l}.376(* *) \\
.000\end{array}$ & 1 & & .904 \\
\hline $\mathrm{CM}$ & Pearson Correlation & $.570(* *)$ & $.500(* *)$ & $-.643(* *)$ & .233 & 1 & .861 \\
\hline
\end{tabular}


H3: Facilitation has a negative impact on workplace stress. It was assumed in research that stress can be minimized through proper facilitation. The result for assumption was checked and found to be true. Stress and facilitation are negatively related. Correlation matrix values are $-0.402(* *)$ with significance 0.000 . Our assumption facilitation has negative impact on the workplace stress is true.

H4: Workplace Stress has the negative relationship with change management. Again, relationship between stress and change management is found to be negative and significant. The results shows that our hypothesis about workplace stress has a negative relationship with change management is true and thus substantiated. The values for this relationship are $-.643\left(^{* *}\right)$ with 0.000 significance level.

$\mathrm{H}_{5}$ : Facilitation has a positive correlation with organizational trust of employees. The relationship between the facilitation and trust is also positive and significant having the correlation values of $0.543\left(^{* *}\right)$ with a significance level 0.000 . Hence our assumption the "facilitation has the positive correlation with organizational trust of employees" is true and supported by the respondents of the study.

H6: Trust and Change management in organizations are positively correlated. Trust and change management have a positive and significant relationship with each other, having a correlational value of $0.633\left(^{* *}\right)$ having a significance level of 0.000 . Hence our supposition "Trust and Change management in organizations are positively correlated" is supported by respondent and stands true.

\section{DISCUSSION}

Contemporary organizational structure, use of advanced technologies and workplace problems do oppose process of change management all over world. And there is a fear that modern technology and ways of managing organizations will negatively affect workplace in context of issues relating to workers. This feeling not only disturbs the attachment of the employee to organization but also minimizes the productivity and other outcomes. But most important point is that the organization have to adopt changes according to need of the day and provide their services and offerings up to the mark. On the other hand, human by nature is resistant to change. One of the main reasons for this is either they do not know about advantages of change or they feel that it will affect their jobs negatively. In a more specific word, two elements due to which people resist any organizational change are the lack of knowledge about advantages and fear of negative impact as per available evidence.

Thus, those elements which create such confusion need to be eliminated for organizational change management. And all of workers and stack holders should be informed about the benefits of any organizational change. And they should be provided with enough evidence that change is beneficial for both the workers and the organization. In this study, three elements; Stress, Trust, and Ethics were discussed as the factors having a strong relationship with change management. It is found out that stress can be reduced over proper facilitation in organization which will make employees accept the organizational change easily. If there is a large stress in the organization, its employees think that change is an addition to elements of their stress and will further increase it. But if the employees get facilitation for reducing their workplace stress, they will feel positive about change. This will not lead them to accept organizational change but also compels them for bringing that organizational change. Results approve our assumption and given in the analysis section discussed earlier. 
Like stress, trust is also one of the important factors having a very strong relationship with the organizational change. If the level of trust is low, the employees will not accept any organizational change. Therefore, they should be provided with enough trust on the organization that they feel that any change the organization is going to adopt is not only for the progress of the organization but also for the advancement of workers. As the research result shows, trust can be built through proper facilitation with such friendly environment that the employees feel the change not only irrevocable but their need also. Last but not the least, ethics is also the very important factor for organizational change management. The management needs to develop ethical code of conduct along with practical ethical environment for any organizational change they want to implement. Evidence from the result section proves our claim. Therefore, it is crystal clear that before any organizational change, the management needs to provide the stress less, trustful and the ethical environment to its employees. This will feel them their importance in the organization and will develop a strong relationship with it. So earlier to any organizational change, the workers should be facilitated in a way to reduce their stress, enhance their trust and feel worthy of being a part of organization.

\section{CONCLUSION}

The organizations cannot bring change management merely with the use of modern technology and the facilities. It is true that the modern technologies and facilities are changing the work environment from one extreme to the other extreme regarding productivity and profitability but it is impossible without the active and positive involvement of workers. Therefore, it is necessary for public sector organizations to facilitate the human behavioral factors like, the ethical behavior and understanding, ensure trust on management and supervisors, and to lessen workplace stress by introducing ethical and friendly work environment for achieving the desired organizational change and its management. This research finds out the relationship between the facilitation and Ethics, Trust and stress with the significant values as the pre-requisite for organizational change management. Therefore, it is concluded that before introducing any organizational change in an organization the management should first facilitate the organizational environment to be more ethical, trusty and the stress less. This will increase the motivation of the employees, who are the actors of the change and will accept cordially what the organizational management desires to introduce.

Therefore, based upon the results and conclusion of study, following recommendations have been extracted.

1. Public sector organization should facilitate employees to develop trust for their policies and change.

2. They should make organizational environment friendly and less stressful so that employee enjoy long term relationship and see themselves valuable. This will again make change process acceptable and the employees will contribute to it.

3. Ethical standards must be high for any change. If the employees believe that organization is ethical practically, they will contribute instead of resist change.

4. Although the research was conducted in the public sector organization, we believe that it is equally applicable in many other sector organizations. As it enhances the focus for any change/ transformation on its human resource, it could be beneficial for human resource managers and strategy makers.

\section{REFERENCES}

Ahmed, S. F. (2011). Issues and Solution of Ethical Climate and Turnover Intention in PTCL, Journal of Education and Vocational Research 2, (5), 183-196. 
Awan, Z. (2011). Organizational Commitment of IT Professionals in Public Sector. Journal of Social and Development Sciences, 2 (6), 266-274.

Bachmann, R. (2001) Trust, Power and Control in Trans organizational Relations. Organization Studies, 22(2), 337-365.

Bamberger, R., \& Walter, P. (2010). "Interpersonal Trust - Attempt of a Definition". Scientific report, Technische Universität München.

Barlow, J., Roehrich, J. K., \& Wright, S. (2010). De facto privatization or a renewed role for the EU? Paying for Europe's healthcare infrastructure in a recession. Journal of the Royal Society of Medicine. 103:51-55.

Berle, A. A., \& Means, G. C. (1932). The Modern Corporation and Private Property. New Jersey: Transaction Publishers.

Bero L. A., Grilli, R., Grimshaw, J. M., Harvey, E., Oxman, A. D., \& Thomson, A. T. (1998). Closing the gap between research and practice: an overview of systematic reviews of interventions to promote implementation of research findings. British Medical Journal $317,465-468$.

Burns, R. A., Peter, B., \& Kaarin, J. (2016). An examination of the long-term impact of job strain on mental health and wellbeing over a 12-year period". Social Psychiatry and Psychiatric Epidemiology. 51 (5).

Cabrera, K. (2018). The Ethics for Governance. The Scientific e-Resources. ISBN 978-1-83947390-6.

Cofta, P. (2007). Trust, Complexity and Control: Confidence in a Convergent World. John Wiley and Sons.

Creasey, T. (2019). The ADKAR, Core to the People Side of Change, the Prosci, accessed 27 August 2019.

Cyert, R., \& March, J. (1963). A Behavioral Theory of the Firm, The Prentice-Hall, Englewood Cliffs, NJ.

DeNeve, K. M. (1999). "Happy as an Extraverted Clam? The Role of Personality for Subjective Well-Being". Current Directions in Psychological Science, 8 (5): 141-144.

Dickey, R., \& Colin, K. (2015). A fault in our design. "Perhaps a brighter technological future lies less in the latest gadgets, and rather in learning to understand ourselves better, particularly our capacity to forget what we've already learned. The future of technology is nothing without a long view of the past, and a means to embody history's mistakes and lessons."

Dinesen, P., Merlin, S., \& Kim, M. (2020). "Ethnic Diversity and Social Trust: A Narrative and Meta-Analytical Review". Annual Review of Political Science, 23: 441-465.

Dopkeen, J., \& Renee, D. (2014). "Stress in the Workplace: A Policy Synthesis on Its Dimensions and Prevalence.

Editorial Team, Mind Tools (2016). "Kotter's 8-Step Change Model". Mind Tools. Retrieved 18 February 2016.

Fukuyama, F. (1996). The Trust: The Social Virtues and the Creation of Prosperity. The Touchstone Books.

Hayes, John (2014). The Theory and Practice of Change Management. London: Palgrave Macmillan. p. 137.

Henry, O., \& Evans, A. J. (2008). Occupational Stress in Organizations. Journal of Management Research, 8 (3): 123-135.

Hogan, C. F. (2013). Facilitating Cultural Transitions and Change, a practical approach. Stillwater, USA: 4 Square Books. (Available from Amazon), ISBN 978-1-61766-235-5.

http://caae.phil.cmu.edu/Cavalier/80130/part2/II_preface.html

http://www.iep.utm.edu/ethics/

http://www.iep.utm.edu/non-cogn/ 
Ibrahim, M. (2015). Impact of Risk and Ethics on Adoption of Mobile Banking in Pakistan. Journal of Economics and Sustainable Development ISSN 2222-1700 (Paper) ISSN 22222855 (Online), 6, (7).

Kitson A., Harvey G. \& McCormack B. (1998). Enabling the implementation of evidence-based practice: a conceptual framework. Quality in Health Care 7, 149-158.

Lacohée, H., Cofta, P., Phippen, A., \& Furnell, S. (2008). Understanding Public Perceptions: Trust and Engagement in ICT Mediated Services. International Engineering Consortium.

Lewin, K. (1947). Frontiers in Group Dynamics: Concept, Method and Reality in Social Science; Social Equilibria and Social Change. Human Relations, 1: 5-41.

Liu, C., Spector, P. E., \& Shi, L. (2007). Cross-National Job Stress: A Quantitative and Qualitative Study. Journal of Organizational Behavior. 28 (2): 209-239.

Machiavelli, N. (1993). Concerning the way to govern cities or principalities which lived under their own laws before they were annexed. The Prince (in Translation), Wordsworth Reference, Ware.

Mark, G., \& Smith, A. P. (2008). Stress models: a review and suggested new direction. Occupational Health Psychology, European Perspectives on Research, Education and Practice, 3. Nottingham: Nottingham University Press, pp. 111-144.

Marquis, C., \& András, T. (2013). Imprinting: Toward A Multilevel Theory. Academy of Management Annals: 193-243.

Marris, R. (1964). The Economic Theory of Managerial Capitalism, Macmillan, London.

Marshall, J., \& McLean, A. (1988) In Human Inquiry in Action. Developments in New Paradigm Research. (Reason P. ed.), Sage, London.

McCormack, B., \& Garbett, R. (2001) A Concept Analysis of Practice Development. RCN Institute, Oxford.

Metz, T. (2013). The FAST Facilitative Session Leader. Productivity Press, Boca Raton, FL. ISBN 978-1-46651251-1.

Mollering, G. (2005). The Trust/Control Duality: An Integrative Perspective on Positive Expectations of Others. In: Int. Sociology, September, 20(3): 283-305. 2005.

NIOSH. (1999). Stress at Work. U.S. National Institute for Occupational Safety and Health, DHHS (NIOSH) Publication Number 99-101.

Nooteboom, B. (2017). Trust: Forms, Foundations, Functions, Failures and Figures. Edward Elgar Publishing.

Oliveira, N., \& Fabrice, L. (2019). The Dark Side of Interorganizational Relationships: An Integrative Review and Research Agenda. Journal of Management. 45(1): 231-261.

Oxman, A. (1994). No Magic Bullets: A Systematic Review of 102 Trials of Interventions to Help Health Care Professionals Deliver Services More Effectively and Efficiently. North East Thames Regional Health Authority, London.

Paul, R., \& Linda, E. (2006). The Miniature Guide to Understanding the Foundations of Ethical Reasoning. United States: Foundation for Critical Thinking Free Press.

Public sector. (2016). Investor words, Web Finance, Incorporation. 2016.

Rogers, B. L. (1994). Concepts, analysis and development of nursing knowledge: The evolutionary cycle. In Models, Theories and Concepts (Smith J. ed.), Blackwell Science, Oxford, 21-30.

Rush, G. (2015). "The FoCuSeD ${ }^{\text {Tм }}$ Facilitator Guide", (2015) Professional Misfits, ISBN 978-09795799-1-2.

Scott, W., \& Richard, M. (2008). Institutions and Organizations (3rd ed.). London: Sage Publications Ltd.

Shahab, L., Jennifer, A., Waller, J., Samuel, G. (2018). "Prevalence of beliefs about actual and mythical causes of cancer and their association with socio-demographic and health-related characteristics: Findings from a cross-sectional survey in England". European Journal of Cancer, 103: 308-316. 
Simon, C., \& Marco, T. (2018). Feeding the behavioral revolution: Contributions of behavior analysis to nudging and vice versa. Journal of Behavioral Economics for Policy, 1 (2): 9197.

Skelsey, D. (2013). "Why Do People in Business Resist Change?". Project Laneway. Retrieved 8 February 2015.

Teasdale, E. L. (2006). "Workplace stress". Psychiatry 5 (7): 251-254.

The Center for Responsive Politics." OpenSecrets.org. Center for Responsive Politics, 16 May 2017. Web. 11 June 2017.

Thomson, K. (1993). Managing your Internal Customer: The Key to Better Results, Pitman Boston, MA

Upadhaya, B., Munir, R., \& Blount, Y. (2014). Association between Performance Measurement Systems and Organizational Effectiveness. International Journal of Operations \& Production Management, 34(7), 2-2.

What is the Public Sector? Definition \& Examples. (2016). Retrieved June 10, 2017.

WHO (2015). Stress at the workplace. www.who.int. Retrieved 2015-10-27).

William B. (2004). Transitions: Making Sense of Life's Changes, Revised 25th Anniversary Edition Paperback - August 11, 2004.

Williamson, O. (1964). The Economics of Discretionary Behavior: Managerial Objectives in a theory of the Firm, Prentice Hall, Englewood Cliffs, NJ.

Workplace Stress Greater for Women. (2010). OfficePro. Aug/Sep 2010; 70, 5; ProQuest. pg.8.

Zheng, J. Roehrich, J. K., \& Lewis, M. A. (2008). The dynamics of contractual and relational governance: Evidence from long-term public-private procurement arrangements. Journal of Purchasing and Supply Management. 14(1): 43-54. 